\title{
The Determinants of Environmental Disclosure Quality: Empirical Evidence from Indonesia
}

\author{
Pricilia Angela \\ Faculty of Economics and Business \\ Universitas Padjadjaran \\ Sofik Handoyo \\ Faculty of Economics and Business \\ Universitas Padjadjaran
}

\begin{abstract}
Sustainability issues have increased the need for stakeholder toward environmental information disclosure. Quality of environmental information is pivotal for stakeholders to assess a firm's environmental performance properly. This study examines the relationship between a firm's characteristics and environmental disclosure quality. Firm's characteristics in this study refer to the size, ownership concentration, age, and leverage. Content analysis of sustainability reporting was applied in this study. The study involved 33 listed firms in Indonesia Stock Exchange (IDX) that are consistently issued sustainability reporting during 2014-2016. Simultaneously test indicated that characteristics of the firm significantly explain the variance of environmental disclosure quality. However, partially test showed that leverage is the only variable significantly influenced environmental disclosure quality.
\end{abstract}

Keywords: Sustainability; Stakeholder; Environmental; Quality; Characteristics; Leverage

\section{Introduction}

Awareness of environmental issues has increased significantly over the past few decades (Ham et al., 2016). The United Nation released Sustainability Development Goals (SDGs) resolution in 2015 to respond to environmental issues (Lim et al., 2018). Since then, environmental issues have become critical issues for firms, public sector organisations, and the international community. Firms face public pressure for environmental accountability more intense than before (Van De Burgwal et al., 2014). Therefore, the firms must have transparency on environmental responsibilities in order to get legitimation from the stakeholders. The existence of business activities should not undermine the quality of the environment. Pressure from stakeholders that demand environmental protection programs from the firms makes environmental information disclosure necessary (Albertini, 2014). The practice of environmental information disclosure in general founded in media such as annual reports and sustainability reporting (Albertini, 2014)

Environmental information disclosure is a form of firm's accountability to the stakeholders. It is useful for stakeholders to assess their environment policy orientation (Karthikeyani \& Angalakshmi, 2013). It is, therefore, the quality of environmental disclosure become the firms should consider an important aspect. The firm's environmental disclosure is very much influenced by the inherent factors of the firm's characteristics (Gantyowati \& Agustine, 2017). Several factors, such as firm size, ownership concentration, firm age, and financial leverage, are considered proportional to the company's concern to disclose sustainability report (Akbas, 2014). In previous research, a firm's characteristics have been associated frequently with financial information quality but lack attention to non-financial information such as environmental information quality (Ismail \& Rahman, 2016). Therefore, understanding the determinants of environmental information disclosure quality is relevant to be conducted.

Issuing sustainability reporting by the firms in Indonesia is voluntary (Djajadikerta \& Trireksani, 2012). Sustainability reports in Indonesia have been more than a decade since the government enacted Incorporated Company Constitution No. 40 in 2007, requiring firms to make reports on their social and environmental 
responsibility activities, especially natural extraction firms (Limited Liability Company, 2007). Even though rules and regulation already in place, however, content and format of environmental information disclosure in Indonesia were varied widely (Djajadikerta \& Trireksani, 2012). Internationally, practice environmental information indicates the same condition because there is no international consensus preparing sustainability reports (Hedberg and Malmborg, 2003). Global Reporting Initiative (GRI) is a guideline of sustainability reporting commonly used by the firms in Indonesia (Djajadikerta \& Trireksani, 2012; Gantyowati \& Agustine, 2017). According to the GRI Standards, there are three main components of disclosures regulated: environment, social, and economics (GRI, 2013).

Environmental sustainability is a crucial issue for many countries, especially Indonesia, where the economy relies heavily on exploiting natural resources. The stakeholders expect transparency and accountability from corporate activities through environment information disclosure. Substantial researches have been conducted regarding sustainability reports. However, the extent of evaluating environmental disclosure quality of sustainability reports has not been adequately investigated (Ismail \& Rahman, 2016). Previous research on environmental disclosure mostly uses content analysis based on checklist items disclosure based on specific standards (Ismail \& Rahman, 2016). Using content analysis with checklist items approach without further detail analysis has a significant flaw, which lacks the understanding quality of environmental information disclosure (Michelon et al., 2015). This study investigated environmental disclosure in sustainability reports comprehensively using content analysis with a levelling approach. This research was intended to identify the factors that affect the quality of listed firms' quality of environmental information disclosure in Indonesia.

\section{Literature Review And Hypotheses Development}

\section{Legitimacy and Stakeholder Theory}

The quality of environmental disclosures is influenced by how the sustainability report will help the firms show responsibility (Hallgren \&
Johansson, 2016). The theoretical frameworks that perfectly fit to explain entities' motivation to issue environmental information disclosures are legitimacy and stakeholder theories (Gunawan, 2007). The basic assumption of legitimacy theory is that the existence of the business entities and its activities are acceptable as long as not contradicting social values (Djajadikerta \& Trireksani, 2012; Mobus, 2005; Van der Laan, 2009). The mutual understanding between business entities and community are bound with the social contract. Even though the social contract's nature is informal and merely based on gentlemen agreement, the community has coercive power to force business entities to accommodate community interests. It implies that any violation of social values by business entities is potentially creating social conflict and undermine achievement business goals. Business entities that are not operating in ways consistent with community expectations will get social sanction (Deegan, 2002).

Stakeholder theory assumes that the management of the firms and stakeholders are the partner that cannot be divided in order to achieve successful business organisation (Kent \& Chan, 2009; Marco et al., 2019; Orij, 2010; Van der Laan, 2009). The management is needed to run the firms professionally. Meanwhile, stakeholders act as controllers that monitor the organisation's operation. Stakeholder theory assumes that some groups or individuals influence and be influenced to achieve organisational goals (Saleh et al., 2014), and it refers to internal and external stakeholders (Kent \& Chan, 2009). An internal stakeholder is a management, and external stakeholders refer to parties such as shareholders, government, community, media, and NGOs (Kent \& Chan, 2009). It is essential for management to achieve not only the business organisation goals but also external stakeholders interests. Protecting the quality of the environment from the negative impact of industrialisation must be the primary concern if the company wants to build trust reputation and good relations with external stakeholders (Alamgir \& Uddin, 2017)

\section{Environmental Disclosure Quality}

The quality of environmental disclosure is the extent to which environmental information presented comprehensively and clearly so that the users can make a proper assessment 
(Hallgren \& Johansson, 2016; Susi, 2009). The more detailed environmental information disclosed by the firms, the higher the quality of environmental disclosure (Ane, 2012). Disclosure quality revealed in the sustainability reports is measured based on completeness and comprehensiveness of the environmental information presented using certain standard (Wang \& Zhang, 2019). It refers to qualitative and quantitative information to inform the users concisely (Ane, 2012; Ismail \& Rahman, 2016).

There are three types of disclosures: adequate, fair and full disclosure (Hallgren \& Johansson, 2016). Adequate disclosure refers to a minimum standard present in sustainability reporting (Hallgren \& Johansson, 2016). The fair disclosure refers to moderate disclosure, and this type of disclosure is generally found in majority sustainability reporting (Hallgren \& Johansson, 2016). Full disclosure is defined as providing comprehensive information that is significantly influencing judgments and decisions that users will take (Hallgren \& Johansson, 2016).

Assessing environmental information disclosure quality using levelling scoring method has more complicated stages. First, the assessors identify various environmental information available in sustainability reporting. Second, compared the information available information with the certain sustainability reporting standard used. Third, putting value for each information available using levelling value of information (Ane, 2012; Hallgren \& Johansson, 2016; Ismail \& Rahman, 2016). Items that get the highest score or weight reflect those environmental issues that are most often informed and are highest requested by stakeholders and vice versa. Providing comprehensive environmental information disclosure will be very important for delivering complete information for the community and stakeholders. The more comprehensive and detailed environmental information presented by the firms implies openness information and the adoption of full disclosure principles (Hasseldine et al., 2005). With the increasing quality of environmental disclosure, the firms will get some benefits such as perceived accountability and building company image (Wang et al., 2016)

\section{Firm's Size and Environmental Disclosure Quality}

Firm size refers to the scale of the firm, which is in general associated with total assets. It consists of total firm resources, market capitalisation, equity market condition, and total sales (Gantyowati \& Agustine, 2017). Researchers who studied the relationship of characteristics of the Firm and environmental disclosure were found frequently using total assets as a proxy to measure firms size (Djajadikerta \& Trireksani, 2012; Gantyowati \& Agustine, 2017). Community assessment toward business organisation is greatly influenced by typical characteristics of the firm, such as the size (Deegan, 2002). Large listed companies will generally be more vulnerable to public attention. Large firms naturally get more public exposure due to their impact on stakeholders is visible compared to small firms.

Taxation, labour policy, and impact of business operation on environment and society are issues found in big scale firms. Therefore, larger firms will take higher societal existence and involvement in environmental responsibility than smaller firms. Since the large firms are the centre of attention of stakeholders, they tend to be prudent to take care of sensitive issues such as the environment. One of the sensitive issues in industrialisation is the impact of business operation on environmental quality. Degradation of environmental quality is blamed much more on large-scale firms than small scale firms (Akbas, 2014). It leads to the behaviour of the firms to avoid anything that creates conflict with the stakeholders. It is expected that large scale firms tend to have a quality of environmental information disclosure better than small scale firms. Therefore, the following hypothesis is proposed.

$\mathrm{H}_{1}$ : The bigger Firm's size, the higher environmental disclosure quality will be

\section{Ownership concentration and Environmental Disclosure Quality}

The ownership concentration is the distribution of the firm's shares dominated by specific stakeholders. It is believed that stock control influences information disclosure behaviour among firms (Ghazali, 2007). The broader distribution of the firm's ownership will result in a higher level of information asymmetry, encouraging higher environmental disclosure. Companies with multiple owners are expected 
to disclose more information than companies with concentrated ownership to avoid asymmetric information (Reverte, 2009). The nature of stakeholders' controls will affect the company's performance, including environmental disclosure because of the dependence on each party's strategic positions and alignment of interests (Braga et al., 2015). Previous researches show that the possibility of information asymmetry will encourage higher environmental disclosure (Reverte, 2009). Information asymmetry occurs because there are many stakeholders, while the firm's information submitted is still on the personal range. In connection with the stakeholder theory, the increasing number of stakeholders means the demands to fulfil the community's values are also higher, so the firms' disclosures will be even higher. Conversely, firms with concentrated ownership tend to have less motivation in disclosing environmental information the firms can have financial sources from internal. According to the discussion, it is expected that having broader ownership will motivate firms to disclose environmental information and contrary to ownership concentration. Therefore, the following hypothesis is proposed

$\mathrm{H}_{2}$ : The higher Firm's ownership concentration, the lower environmental disclosure quality will be

\section{Firm's Age and Environmental Disclosure Quality}

The firm age is defined as the time off from the beginning establishment until now or from its merger (Loderer \& Waelchli, 2010). It is believed that the firms will become more experience in line with the length of time the firm operating (Gantyowati \& Agustine, 2017). Firm's age can be a perfect indicator to measure the business organisation's sustainability (Loderer \& Waelchli, 2010). When the firm is getting older, the firm tends to be more systematic, and innovation activities can also develop faster supported by the knowledge to produce new output (Noordin \& Mohtar, 2014). Firms that have such experience will be able to improve their overall performance. The longer time the company operates, there will be more interaction with the outside community for building a public image. An older company will involve more social responsibility, including environment than the younger company (Deegan, 2002). Firm age is divided into the young firm and matured Firm (Noordin \& Mohtar, 2014). A matured firm is a firm whose products are well known and have loyal customers. The matured firm has a constant growth rate and has equally well-established competitors. The matured firm will get more attention from the public by having loyal customers and maintaining its reputation (Deegan, 2002). The firm's growing maturity and the obligation to make environmental disclosures to meet the community and stakeholders' expectations become increasingly high. Therefore, the following hypothesis is proposed.

$\mathrm{H}_{3}$ : The older firms tend to have better environmental disclosure quality than the younger firms

\section{Financial Leverage and Environmental Disclosure Quality}

Leverage shows how much the firms depend on creditors in financing the business operation (Wahyuningsih \& Mahdar, 2018). The firms with a high degree of leverage depend heavily on external loans. Meanwhile, firms with low financial leverage use more capital to finance business operations than loans (Gantyowati \& Agustine, 2017; Wahyuningsih \& Mahdar, 2018). Therefore, the level of firms leverage describes the company's financial risk (Hallgren \& Johansson, 2016; Wahyuningsih \& Mahdar, 2018). Environmental activities need sources of financing in order to implement it. The most priority for firms with high leverage is maintaining core business activities (Gantyowati \& Agustine, 2017). Naturally, environmental activities are considered secondary activities by most business organisations (Hallgren \& Johansson, 2016). Since there are financial sources limitation for firms with high financial leverage, activities related to the environmental program are less, affecting environmental information disclosure in annual reports and sustainability reports. Firm's with low financial leverage indicates that the firm is financially healthy. Financially healthy organisations can more easily meet their obligations to owner-stakeholders and allocate the financial resources available for environmental protection activities. Therefore, it is expected that firms with low financial 
leverage will present environmental information disclosure better than firms with high financial leverage. Therefore, the following hypothesis is posited:

H4: The Firm's with higher financial leverage will have a lower environmental disclosure quality

\section{Research Method}

\section{Population and Sample}

The population in this research is all listed firms in Indonesia Stock Exchange. The nonprobability sampling methods, which is the purposive sampling, was applied. Purposive sampling is a sampling technique in which the researcher will obtain information from readily or conveniently available data from specific target groups. The sample's criteria were all listed companies in Indonesia Stock Exchange that published a sustainability report and annual report. The period of investigation is the year of 2014 to 2016 (3 years). That period was chosen because the firms began to routinely issue a sustainability report in these years, while for 2017, the firms have not entirely published a sustainability report. From the sample selection process, there are 33 firms each year that meet the criteria. Therefore, total sample data were used in this study is 99 (33 firms $x 3$ years)

Table 1. Sample Distribution

\begin{tabular}{lcc}
\hline \multicolumn{1}{c}{ Industry Sector } & Sample Size & $\begin{array}{c}\text { Percentage of } \\
\text { Total Sample }\end{array}$ \\
\hline Agriculture & 2 & $6 \%$ \\
Basic Industry \& Chemicals & 3 & $9 \%$ \\
Consumer Goods Industry & 1 & $3 \%$ \\
Finance & 9 & $27 \%$ \\
Infrastructure, Utilities, \& Transportation & 6 & $18 \%$ \\
Mining & 5 & $15 \%$ \\
Automotive \& Components & 1 & $3 \%$ \\
Property, Real Estate, \& Building Construction & 3 & $9 \%$ \\
Trade, Services, \& Investment & 3 & $9 \%$ \\
\hline Total & $\mathbf{3 3}$ & $\mathbf{1 0 0 \%}$ \\
\hline
\end{tabular}

\section{Data and Measurement}

The data source was collected from the environmental disclosure information given in the sample firms' annual and sustainability report. Content analysis was applied in order to obtain environmental disclosure score. Environmental disclosure score was generated using eight levels rating method presented in Table 2

Table 2. Environmental Information Disclosure scoring

\begin{tabular}{cl}
\hline Score & \\
\hline 0 & No Disclosure \\
1 & Disclosure the monetary information only \\
2 & Disclosure the non-monetary information only \\
3 & Disclosure in the form of qualitative information \\
4 & Disclosure in the form of combination between qualitative and monetary information \\
5 & Disclosure in the form of combination between qualitative and monetary information \\
6 & $\begin{array}{l}\text { Disclosure in the form of a combination between monetary information and non-monetary } \\
\text { information }\end{array}$ \\
7 & $\begin{array}{l}\text { complete disclosure by writing a combination of qualitative, monetary and non-monetary } \\
\text { information }\end{array}$ \\
\hline Sources: (Ngoc \& Hang 2016$)$
\end{tabular}

Sources: (Ngoc \& Hang, 2016)

The firm's total asset, distribution of the equity, length time of the firm established, and debt to finance operating activities are dimensions to measure firm size, ownership concentration, firm age, and financial leverage. To avoid multicollinear and normal distribution data, raw 
data of the firm's size and firm's age dimension were transformed into logarithmic natural (Ln).
Summary of measurement each variable is presented in Table 3

Table 3. Variable and Measurement

\begin{tabular}{lll}
\hline \multicolumn{1}{c}{ Variable } & \multicolumn{1}{c}{ Dimension } & \multicolumn{1}{c}{ Indicator } \\
\hline $\begin{array}{l}\text { Quality of } \\
\text { Environmental } \\
\text { Disclosure }\end{array}$ & $\begin{array}{l}\text { The completeness overview appraisal of the } \\
\text { environmental issues disclosed by the } \\
\text { company }\end{array}$ & $\begin{array}{l}\text { Environmental Disclosure } \\
\text { score }\end{array}$ \\
\hline Firm Size & Size of the total asset of the company & Ln (total assets) \\
\hline $\begin{array}{l}\text { Ownership } \\
\text { Concentration }\end{array}$ & $\begin{array}{l}\text { Distribution of equity relating to votes, } \\
\text { capital, and identity of the equity owner }\end{array}$ & $\begin{array}{l}\text { shares held by the public to } \\
\text { outstanding share ratio }\end{array}$ \\
\hline Firm Age & Length time of the firm established & Ln (firm age) \\
\hline Financial Leverage & Debt to finance operating activities & debt to equity ratio \\
\hline
\end{tabular}

Analysis

Multiple linear regression analysis was applied in this study. Regression analysis is a statistical analysis to determine the direction of the relationship between the independent variable and the dependent variable. The dependent variable in this study is the quality of environmental disclosure. Meanwhile, firm size, ownership concentration, firm age, and financial leverage were treated as an independent variable. The significant level was used to analyse whether the proposed hypothesis is accepted or rejected is Alpha $(\alpha)$ 0.05 . SPSS software version 23 was used to process the data. The multiple linear regression equation to analyse was formulated as follows:

QEDit $=\alpha+\beta 1$ FSit $+\beta 2$ OCit $+\beta 3$ FAit + $\beta 4 \mathrm{FLit}+\varepsilon$ it,

where QED is the quality environmental information disclosure, $\mathrm{i}$ is the variables, $\mathrm{t}$ is the period of variables, FS is the firm size, OC is ownership concentration, FA is firm age, FL is financial leverage, and $\varepsilon$ is error

\section{Results and Analysis}

The study was intended to analyse the firm's characteristic size, ownership concentration, firm's age, and financial leverage as factors determining environmental information disclosure quality. Firm's characteristics were believed as the primary determinant that makes a difference between firms in terms of its environmental performance. One of the indicators of environmental performance can be identified from the quality of environmental information disclosure.

The first hypothesis was designed to evaluate the relationship between the firm's size and quality of environmental information disclosure. Theory suggests that a bigger firm has more resources to conduct business activities compared with a smaller firm. Part of business activities is preparing and issuing financial and non-financial information, including environmental information. Due to its resources, big scale firms can make comprehensive environmental information required by the public. Statistical test results, however, were not supporting the proposed hypothesis. A one-tail test of Pearson correlation (Table 3) was insignificant and negative $(r=-0.157)$. It implies that a firm's size is not associated with the quality of environmental information disclosure. Surprisingly, the sign of the correlation is negative. It means that the big scale firms are relatively to have worse environmental information quality than small-scale firms. In line with the correlation analysis, multiple regression analysis results (Table 4) indicates that firm's size is insignificant to explain the variance of environmental disclosure quality $(\mathrm{sig}=0,258, \mathrm{p}>0.05)$. It means that big scale firm does not guarantee that the firm will have a good or excellent quality of environmental information disclosure. On the contrary, small firms are not always associated with poor environmental information disclosure quality. Therefore, hypothesis 1 (one) is not supported (see the summary of the hypothesis testing conclusion in Table 5) 
Table 3. Correlation of firm's characteristics and Environmental disclosure Quality

\begin{tabular}{llllll}
\hline & FS & OC & FA & FL & QED \\
\hline FS & 1 & & & & \\
OC & 0.035 & 1 & & & \\
FA & 0.038 & 0.148 & 1 & & \\
FL & $0.531^{* *}$ & $-0.271^{* *}$ & $-0.183^{*}$ & 1 & $-0.453^{* *}$ \\
QED & -0.157 & 0.039 & 0.143 & 1 \\
\hline
\end{tabular}

**. Correlation is significant at the 0.01 level (1-tailed),

*. Correlation is significant at the 0.05 level (1-tailed).

The second hypothesis examined the relationship between ownership concentration and quality of environmental disclosure. Theoretically, the firm with share ownership dominated by the public tends to conduct environmental disclosure better than the firm's majority-owned by an individual. To increase the firm's value, any information disclosed by the firm's financial and non-financial, including environmental information, should positively impact investors. Correlation analysis result indicates no correlation $(\mathrm{r}=0.039)$ between ownership concentration and environmental information disclosure quality. Likewise, multiple regression analysis results (Table 4) indicates that there was no indication ownership concentration explain the variance of environmental disclosure quality ( $\mathrm{sig}=0,158$, $\mathrm{p}>0.05$ ).
Ownership concentration, whether dominated by public or individual, will not affect the quality of environmental disclosure. The result implies that the owner's structural composition did not determine the practice of environmental disclosure in Indonesia. Majority ownership by the public does not necessarily make listed Firm in Indonesia have a good or excellent quality of environmental disclosure. On the other hand, structure ownership dominated by an individual is not always associated with inadequate environmental disclosure. It implies that the owner's structure did not influence the firm's behaviour in disclosing environmental information. Therefore, hypothesis 2 (two) is not supported (see the summary of the hypothesis testing conclusion in Table 5)

Table 4. Quality Environmental Disclosure as Function of Firm's Characteristics

\begin{tabular}{lccc}
\hline \multicolumn{1}{c}{ Variable } & $\begin{array}{c}\text { Unstandardised } \\
\text { Coefficient }\end{array}$ & t & Sig \\
\hline Constant & -4.285 & -0.168 & 0.867 \\
\hline Firm Size & 1.056 & 1.231 & 0.221 \\
\hline Ownership Concentration & -0.116 & -1.266 & 0.209 \\
\hline Firm's Age & 0.010 & 0.590 & 0.557 \\
\hline Firm's Financial Leverage & $-0.022^{*}$ & -4.721 & 0.000 \\
\hline F & $7.013^{*}$ & & 0.000 \\
\hline R Square & 0.230 & & \\
\hline Adjusted R Square & 0.197 & & \\
\hline${ }^{*}$ p $<.05$ & & &
\end{tabular}

The third hypothesis tested the relationship between a firm's age and environmental information disclosure quality. The theoretical framework assumes that the firms' maturity in terms of the establishment's length will determine its experience. It includes experience in terms of preparing environmental reporting to the public. Testing revealed a correlation of 0.143 , which is insignificant at the 0.05 alpha level (Table 3). It means that there was no association between the firm's maturity and its environmental information disclosure quality. In line with correlation analysis result, multiple regression analysis results (Table 4) shows that firm's age had no significant evidence to explain the quality of 
environmental information variance (sig = $0.098, p>0.05)$. It implies that the firm's longer establishment will not make the quality of environmental information disclosure better. On the other hand, the newly established firm is not always associated with insufficient environmental information disclosure. The result indicates that the firm's maturity may increase its experience; however, it is not always relevant if associated with preparing good/excellent environmental information disclosure. Therefore, hypothesis 3 (three) is not supported (see the summary of the hypothesis testing conclusion in Table 5)

The fourth hypothesis argued that the firm's financial leverage and information disclosure quality would be negatively correlated. Financial leverage is associated with the firm's financial dependency on the creditor to finance business operation. The higher financial leverage indicates that the composition of debt is higher than the firms' equity. High financial leverage is one indicator that can evaluate the firm's financial health and predict its bankruptcy. Firms with high financial leverage have a risk to face financial distress and sustainability business operation. Financial health is the primary indicator widely used to assess business performance. It is manifestation how the business organisation managed. It includes the way financial reporting and nonfinancial reporting, such as environmental reporting prepared. Firms with low financial leverage were predicted to have excellent or good environmental information disclosure quality.

Meanwhile, firms with high financial leverage were expected to have low environmental information disclosure quality. The correlation between financial leverage and environmental disclosure quality (Table 3 ) was found to be high and statistically significant $(\mathrm{r}=$ $-0.453, p<0.01)$. Financial leverage also explains a significant percentage of the variance in environmental disclosure quality in the regression analysis (Table 3, $\mathrm{p}<0.05$ ). Based on correlation analysis and regression analysis, it can be interpreted that the firms that have low financial leverage tend to have a good or excellent quality of environmental disclosure and vice versa. Therefore, hypothesis 4 is supported (see the summary of hypothesis testing conclusion in Table 5)

Table 5. Summary of hypothesis testing

\begin{tabular}{lccc}
\hline Model & $\begin{array}{c}\text { Significant } \\
\text { level }(\boldsymbol{\alpha})\end{array}$ & p-Value & Conclusion \\
\hline Firm's Size $\rightarrow$ Quality Information Disclosure & 0.05 & 0.221 & Insignificant \\
\hline $\begin{array}{l}\text { Ownership Concentration } \rightarrow \text { Quality Information } \\
\text { Disclosure }\end{array}$ & 0.05 & 0.209 & Insignificant \\
\hline Firm's Age $\rightarrow$ Quality Information Disclosure & 0.05 & 0.557 & Insignificant \\
\hline $\begin{array}{l}\text { Firm's Financial Leverage } \rightarrow \text { Quality Information } \\
\text { Disclosure }\end{array}$ & 0.05 & 0.000 & Significant \\
\hline
\end{tabular}

The research proposed a model that characteristics of the firms, namely the firm's size, ownership concentration, firm's age, and the firm's financial leverage are a function of environmental information disclosure quality. The multivariate regression analysis presented in Table 4 indicates that the model is significant $(\mathrm{F}=7.013, \mathrm{p}<0.05)$. It means that the firm's size, ownership concentration, firm's age, and the firm's financial leverage simultaneously are determinant of environmental information disclosure quality. The testing model revealed $\mathrm{R}$-Square of 0.230 , which is significant at the 0.05 alpha level. It implies that characteristics of the firms, namely the firm's size, ownership concentration, firm's age, and the firm's financial leverage, simultaneously influence $23 \%$ on environmental disclosure quality. The remaining $(77 \%)$ is influenced by other variables that are not investigated in this study. The individual contribution of each firm's characteristic is presented in Table 6. Based on information in Table 6, the firm's characteristic, namely, financial leverage contributed the highest $(25 \%)$ to environmental information disclosure quality. Meanwhile, the firm's size, ownership concentration, and age contributed to the environmental information disclosure quality of $1 \%, 0 \%$, and $-2 \%$ respectively. 
Table 6. Partial Coefficient of Determination

\begin{tabular}{|c|c|c|c|}
\hline \multirow[t]{2}{*}{ Model } & $\begin{array}{l}\text { Standardised } \\
\text { Coefficients }\end{array}$ & Correlations & \multirow[t]{2}{*}{$\begin{array}{l}\text { Partial Coefficient } \\
\text { of Determination }\end{array}$} \\
\hline & Beta & Zero-order & \\
\hline Firm Size & 0,136 & $-0,157$ & $-2 \%$ \\
\hline Ownership Concentration & $-0,122$ & 0,039 & $0 \%$ \\
\hline Firm's Age & 0,055 & 0,143 & $1 \%$ \\
\hline Firm's Financial Leverage & $-0,548$ & $-0,453$ & $25 \%$ \\
\hline Total Effect & & & $23 \%$ \\
\hline
\end{tabular}

The present study was a preliminary investigation of the relationship between the firm's characteristics, namely its size, ownership concentration, firm's age, and firm's financial leverage and environmental information disclosure quality conducted in Indonesia. Results indicate that environmental information disclosure quality seems predictable, based on the firm's financial leverage only. Consequently, this supports one of four firms' characteristics proposed as antecedents of environmental information disclosure quality. The remaining firm's characteristics, namely size, ownership concentration, and age, are not supporting as antecedents of environmental information disclosure quality. Country factors such as public governance (voice and accountability, political stability, government effectiveness, regulatory quality, the rule of law, control of corruption) may have influences that result from this study are not fully predicted as expected. Therefore, in the future, conducting a similar study using comparative study approach involving many different countries is relevant.

Even though most previous studies predicted that the firm's size and firm's age are the determinants of the quality of environmental sustainability, this study's results are not conclusive. Galani, Alexandridis, and Stavropoulos (2011) studied the relationship between a firm's characteristics and environmental disclosure quality in Greece found that a firm's size and firm's age are positively correlated but not significant. A study conducted by Sheng (2013) in China indicated similar results with the previous study conducted in Greece. Therefore, the results found in Indonesia that the firm's size and firm's age are not determinants of environmental disclosure quality is backed up with a similar previous study in Greece and China. Alsaeed
(2006) argued that firms only concern issues that directly impact business operation. In the country where the awareness of stakeholders toward environmental issues is low, environmental information disclosure is not interesting. Even though the company has large total assets, these assets will not be used in environmental protection programs but more significantly to finance other aspects that directly impact firms operation. When a company gets older and reaches its stability, it will tend to be stagnant because it has gained the public trust and does not pay too much attention to the environmental disclosures.

The previous studies regarding the influences of ownership concentration on environmental disclosure quality are also inconclusive. Diantimala \& Amril (2018) studied the effect of ownership structure on Indonesia's environmental disclosure and found that managerial ownership is negatively associated with environmental disclosure. Huang \& Kung (2010) studied drivers of environmental disclosure in Taiwan and found that ownership concentration is insignificant in predicting environmental disclosures' quality. Kaium Masud, Bae, \& Kim (2010) studied environmental sustainability reporting (ESRP) performance in Bangladesh, India, and Pakistan found that ESRP has a positive association with foreign and institutional ownership but no association between ESRP and family ownership. According to the study of Dasgupta (1998), who made a comparison between the capital markets in Indonesia and Mexico, the Philippines, Argentina, and Chile, found that the correlation result was negative. He argued that Indonesia's capital market is inefficient; the consequence is that the market is not interested in secondary information, including environmental information. As a result, companies are reluctant to present information 
that investors do not use or respond. The firms more focus on financial reports that have a direct effect on the firm's value. So that even though the concentration of ownership is spread, the quality of environmental disclosures is not affected

Financial leverage was found negatively significant as the determinant of environmental quality disclosure. This study's result is in line with a previous similar study conducted by Diantimala \& Amril (2018) who studied environmental disclosure in Indonesia. Zhang, Djajadikerta, \& Trireksani (2018) studied Chinese mining, utility and chemical industries in China. The result indicates that leverage was found negatively significantly associated with environmental disclosure. The higher the financial leverage, the higher the demand for investors' environmental disclosures was not proven to be positive. Sulkowski (2010) argued that negative correlation might occur in companies that get pressure from lenders by having high financial leverage and creating a low environmental disclosure. Companies have fears that providing more information about environmental disclosures will bring down their image (Sulkowski, 2010). Based on author perspective, financial leverage is a reflection of the operational performance of the firm. The higher financial leverage means that the firm is relatively not liquid financially. It can affect other firm activities, such as environmental protection programs due to limited financial resources. Since environmental programs are limited conducted by the firm, it makes environmental information disclosure is inadequate.

The practice of environmental information disclosure in Indonesia is voluntary. It may explain why even big scale firms and mature firms are not performing good in terms of its environmental information disclosure quality. Furthermore, the Firm in Indonesia may consider environmental information is secondary information that is not strategic being priority. Typical capital market in Indonesia is inefficient. It refers to a condition that stock price is not a reflection of all information available (Dasgupta et al., 1998). Investor in Indonesia tends to use primary information such as financial reporting rather than non-financial reporting, including environmental reporting. Since investors are not relying on investment decisions based on environmental information, firms consider that environmental information disclosure is less relevant. This study revealed that big scale firms and the mature firm were not motivated to issue good/excellent environmental information disclosure quality. Perceived Less relevancy of environmental information disclosure among firms in Indonesia may explain why the quality of environmental information disclosure is low. Participation of listed firms in Indonesia to disclose environmental information is relatively low. There were 550 firms listed in Indonesia Stock Exchange in 2017. However, only 33 firms that are consistently issued environmental sustainability reporting since 2014. The Indonesia government is not regulating standard guidance for environmental information disclosure since the report is voluntary. To expect good or excellent environmental information disclosure quality, the government's intervention through rules and regulation requires the government's presence likely to improve corporate environmental reporting practice (Akrout \& Othman, 2016). Handoyo (2018) investigated the development and environmental compliance of business organisations using the Indonesia state ministry criteria for the environment. The results indicated that the number of business organisation that participated in environmental assessment by Indonesia state ministry for the environment is continually increasing every year. It means that the institution's role, such as government is fundamental for business practice, including environmental information disclosure.

\section{Conclusion}

Quality of environmental information disclosure is theoretically affected by the characteristics of the firms. The results suggest that only financial leverage is valid to predict the quality of environmental disclosure. Meanwhile, firm' size, ownership concentration, and firm's age were found insignificant to explain the variance of quality of environmental information disclosure quality. To some extent, the results of the study diverge with previous similar studies and at the same time also support previous similar studies. It indicates that the study of the determinants of environmental disclosure quality is still inconclusive. Country-specific may play a significant role that determines the results. 
Therefore, comparative studies involving country-specific as a control variable is highly recommended.

\section{References}

Akbas, H. E. (2014). Company Characteristics and Environmental Disclosure: An Empirical Investigation on Companies Listed on Borsa Istanbul 100 Index. The Journal of Accounting and Finance, April.

Akrout, M. M., \& Othman, H. Ben. (2016). Ownership Structure and Environmental Disclosure in Mena Emerging Countries. Corporate Ownership and Control, 13(4), 381-388. https://doi.org/10.22495/cocv13i4c2p9

Alamgir, M., \& Uddin, M. N. (2017). The Mediating Role of Corporate Image on the Relationship between Corporate Social Responsibility and Firm Performance: An Empirical Study. International Journal of Business and Development Studies, 9(1), 91-111.

Albertini, E. (2014). A Descriptive Analysis of Environmental Disclosure: A Longitudinal Study of French Companies. Journal of Business Ethics, 121, 233-254. https://doi.org/10.1007/s10551-0131698-y

Alsaeed, K. (2006). The association between firm-specific characteristics and disclosure: The case of Saudi Arabia. Managerial Auditing Journal, 21(5), 476496.

https://doi.org/10.1108/02686900610667 256

Ane, P. (2012). An Assessment of the Quality of Environmental Information Disclosure of Corporation in China. Systems Engineering Procedia, 5, 420-426. https://doi.org/10.1016/j.sepro.2012.04.0 64

Braga, C., Silva, P. P. da, \& Santos, A. (2015). Level of Disclosure of Environmental Information in the Electricity Sector: An Empirical Study of Brazil and the Iberian Peninsula. Global Journal of Management and Business Research, 15(9).

Dasgupta, S., Laplante, B., \& Mamingi, N. (1998). Capital market responses to environmental performance in developing countries. In Policy Research Working Paper (No. 1909; Policy Research Working Paper). https://doi.org/10.1016/j.jdeveco.2009.06 .005

Deegan, C. (2002). Introduction: The legitimising effect of social and environmental disclosures - a theoretical foundation. Accounting, Auditing \& Accountability Journal, 15(3), 282-311. https://doi.org/10.1108/09513570210435 852

Diantimala, Y., \& Amril, T. A. (2018). The Effect of Ownership Structure, Financial and Environmental Performances on Environmental Disclosure. Accounting Analysis Journal, 7(1), 70-77. https://doi.org/10.15294/aaj.v5i3.20019

Djajadikerta, H. G., \& Trireksani, T. (2012). Corporate social and environmental disclosure by Indonesian listed companies on their corporate web sites. Journal of Applied Accounting Research, 13(1), 21-36. https://doi.org/10.1108/09675421211231 899

Galani, D., Alexandridis, A., \& Stavropoulos, A. (2011). The Association between the Firm Characteristics and Corporate Mandatory Disclosure the Case of Greece. World Academy of Science, Engineering and Technology, International Science Index 53, International Journal of Social, Behavioral, Educational, Economic, Business and Industrial Engineering, 5(5), 411-417.

Gantyowati, E., \& Agustine, K. F. (2017). Firm's Characteristics and CSR Disclosure, Indonesia and Malaysia Cases. Review of Integrative Business and Economics ResearchOnlineCDROM, 6(3), 131-145.

Ghazali, N. A. M. (2007). Ownership structure and corporate social responsibility disclosure: Some Malaysian evidence. Corporate Governance, 7(3), 251-266. https://doi.org/10.1108/14720700710756 535

GRI. (2013). Sustainability reporting policies worldwide: today's best practice, tomorrow's trends. https://www.globalreporting.org/resource library/carrots-and-sticks.pdf 
Gunawan, J. (2007). Corporate Social Disclosures by Indonesian Listed Companies: A Pilot Study. Social Responsibility Journal, 3(3), 26-34. https://doi.org/10.1108/09574090910954 864

Hallgren, A., \& Johansson, J. (2016). Determinants of Disclosure Quality. University of Gothenburg.

Ham, M., Horvat, M., \& Mrčela, D. (2016). Insights for measuring environmental awareness. ECONVIEWS, 1, 159-176.

Handoyo, S. (2018). The Development of Indonesia Environmental Performance and Environmental Compliance. Journal of Accounting Auditing and Business, $1(1), 74-85$. http://jurnal.unpad.ac.id/jaab/article/view/ $15656 / 7354$

Hasseldine, J., Salama, A., \& Toms, S. (2005). Quantity versus Quality: The Impact of Environmental Disclosures on the reputations of UK Plcs. British Accounting Review, 37(2), 231-248. https://doi.org/10.1117/12.479993

Hedberg and Malmborg. (2003). The GRI and corporate sustainability reporting in Swedish Companies. Corporate Social Responsibility and Environmental Management, 164, 153-164. https://doi.org/10.1002/csr.038

Huang, C. L., \& Kung, F. H. (2010). Drivers of Environmental Disclosure and Stakeholder Expectation: Evidence from Taiwan. Journal of Business Ethics, 96(3), 435-451. https://doi.org/10.1007/s10551-0100476-3

Limited Liability Company, (2007) (testimony of Indonesia Law No.40 of 2017). https://doi.org/10.1017/CBO9781107415 324.004

Ismail, A. H., \& Rahman, A. A. (2016). The quality of environmental disclosure in various reporting media of oil and gas companies in developing countries. Corporate Ownership and Control, 14(1), 203-218.

Kaium Masud, M. A., Bae, S. M., \& Kim, J. D. (2010). Analysis of Environmental Accounting and Reporting Practices of Listed Banking Companies in Bangladesh. https://doi.org/10.3390/su9101717

Karthikeyani, J., \& Angalakshmi, N. (2013).
Corporate Sustainability Reporting in Emerging Economies-A Review and Future Direction. International Journal of Science and Research, 2(11), 252-256.

Kent, P., \& Chan, C. (2009). Application of Stakeholder Theory to the Quantity and Quality of Australian Voluntary Corporate Environmental Disclosures. Corporate Ownership \& Control, 7(1), 394-410. https://doi.org/10.2139/ssrn.447901

Lim, M. M. L., Søgaard Jørgensen, P., \& Wyborn, C. A. (2018). Reframing the sustainable development goals to achieve sustainable development in the anthropocene - a systems approach. Ecology and Society, 23(3). https://doi.org/10.5751/ES-10182-230322

Loderer, C., \& Waelchli, U. (2010). Protecting minority shareholders: Listed versus unlisted firms. Financial Management, 39(1), 33-57. https://doi.org/10.1111/j.1755053X.2009.01065.X

Marco, M., Moneva, J. M., \& Scarpellini, S. (2019). Environmental disclosure and Eco-innovation interrelation. The case of Spanish firms. Spanish Accounting Review, 22(1), 71-85.

Michelon, G., Pilonato, S., \& Ricceri, F. (2015). CSR reporting practices and the quality of disclosure: An empirical analysis. Critical Perspectives on Accounting, 33, 59-78. https://doi.org/10.1016/j.cpa.2014.10.003

Mobus, J. L. (2005). Mandatory environmental disclosures in a legitimacy theory context. Accounting, Auditing and Accountability Journal, 18(4), 492-517. https://doi.org/10.1108/09513570510609 333

Ngoc, L., \& Hang, M. (2016). An Evaluation of Corporate Environmental Disclosures by Vietnamese Listed Firms. The Vietnam Economist Annual Meeting (VEAM) 2016.

Noordin, M. A., \& Mohtar, D. S. (2014). Age: Does it Matter for Firms to Perform? International Journal of Academic Research in Business and Social Sciences, 4(3), 252-260. https://doi.org/10.6007/IJARBSS/v4i $3 / 704$

Orij, R. (2010). Corporate social disclosures in the context of national cultures and 
stakeholder theory. Accounting, Auditing \& Accountability Journal, 23(7), 868889.

Reverte, C. (2009). Determinants of corporate social responsibility disclosure ratings by Spanish listed firms. Journal of Business Ethics, 88(2), 351-366. https://doi.org/10.1007/s10551-0089968-9

Saleh, N., Ahmad, M., \& Ishwerf, A. I. (2014). Forces and Obstacles for Corporate Environmental Disclosure (CED) in Libya: Perspective of Stakeholders. Review of Integrative Business and Economics Research, 3(1), 2304-1013.

Sheng, M. E. N. (2013). Empirical Study on Influencing Factors of Corporate Social Responsibility Performance Degree: From the Perspective of the Nature and Function of State- owned Enterprises in China. Management Science and Engineering, 7(2), 75-79. https://doi.org/10.3968/j.mse.1913035X2 0130702.3379

Sulkowski, A. J. (2010). Environmental Disclosure, Environmental Performance, and Firm Characteristics: An Analysis of S\&P 100 Firms. Journal of Academy of Business and Economics, 10(4), 73-83. https://doi.org/10.2139/ssrn.1861008

Susi. (2009). the Occurrence of Environmental Disclosures in the Annual Reports. JAAI, 13(1), 29-42.

Van De Burgwal, D., José, R., \& Vieira, O. (2014). Environmental Disclosure
Determinants in Dutch Listed Companies. Revista Contabilidade \& Finanças, 2511(64), 60-78.

Van der Laan, S. (2009). The Role of Theory in Explaining Motivation for Corporate Social Disclosures. Australasian Accounting, Business and Finance Journal, Vol 3(Issue 4), Pp 15-29.

Wahyuningsih, A., \& Mahdar, N. M. (2018). Pengaruh Size, Leverage dan Profitabilitas Terhadap Pengungkapan Csr Pada Perusahaan Manufaktur yang Terdaftar di Bursa Efek Indonesia. Jurnal Bisnis Dan Komunikasi, 5(1), 27-36. https://doi.org/10.1097/00006982200502000-00005

Wang, J., \& Zhang, B. (2019). Quality of environmental information disclosure and enterprise characteristics. Management of Environmental Quality: An International Journal. https://doi.org/10.1108/meq-112018-0194

Wang, Yu, H., \& Ahsan, T. (2016). The Impact of Environmental Information Disclosure on Business Performance : Evidence from High-Polluting Industries in China. European Journal of Business and Management, 8(18), 13-21.

Zhang, J., Djajadikerta, H. G., \& Trireksani, T. (2018). Determinants of Corporate Environmental and Social Disclosures in China: A Comparative Study within High-profile Industries. Asian Journal of Finance \& Accounting, 10(1), 308. https://doi.org/10.5296/ajfa.v10i1.12658 